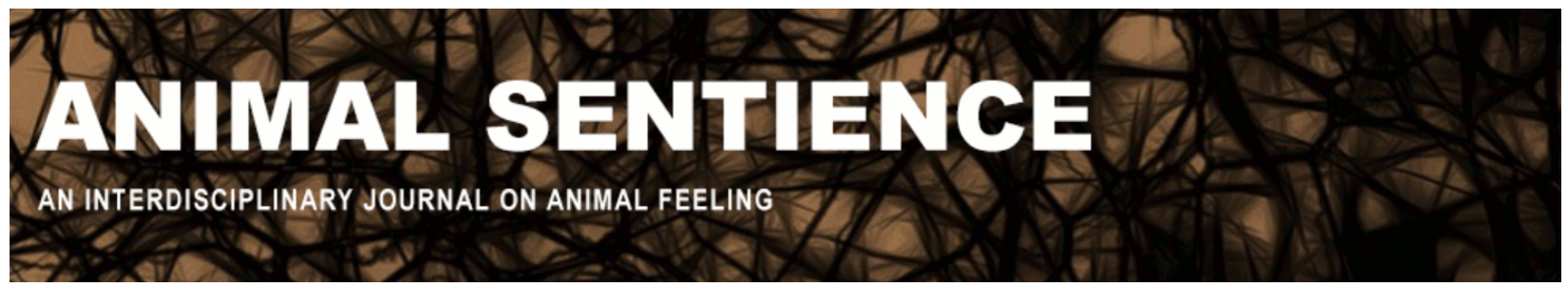

Jones, Robert C. (2018) Fish sentience denial: Muddy moral water. Animal Sentience 21(5)

DOI: $10.51291 / 2377-7478.1325$

Date of submission: 2018-05-10

Date of acceptance: 2018-05-13

(c)

This article has appeared in the journal Animal

Sentience, a peer-reviewed journal on animal

cognition and feeling. It has been made open access,

free for all, by WellBeing International and deposited

in the WBI Studies Repository. For more information,

please contact

wbisr-info@wellbeingintl.org.

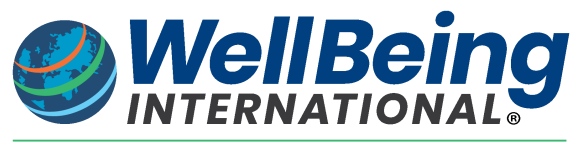

SOLUTIONS FOR PEOPLE, ANIMALS AND ENVIRONMENT 


\title{
Fish sentience denial: Muddy moral water
}

Commentary on Sneddon et al. on Sentience Denial

\author{
Robert C. Jones \\ Department of Philosophy \\ California State University, Chico
}

\begin{abstract}
Sneddon et al. (2018) authoritatively summarize the compelling and overwhelming evidence for fish sentience, while methodically dismantling one rather emblematic research paper (Diggles et al. 2017) intended to discount solid evidence of fish sentience (Lopez-Luna et al. 2017a, 2017b, 2017c, \& 2017d). I explore the larger practical moral contexts within which these debates take place and argue that denials of animal sentience are really moral canards.
\end{abstract}

Robert C. Jones is Associate Professor of Philosophy at California State University. He has published numerous articles and book chapters on animal ethics, animal cognition, and food ethics, and has given over forty talks on animal ethics. $\underline{\text { rcjones.me }}$

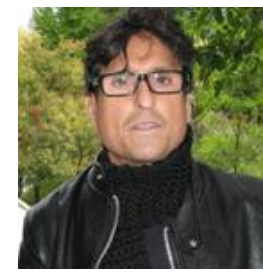

Sneddon et al. (2018) authoritatively summarize the compelling and overwhelming evidence for fish sentience, while methodically dismantling one rather emblematic research paper (Diggles et al. 2017) intended to discount solid evidence of fish sentience (Lopez-Luna et al. 2017a, 2017b, 2017c, \& 2017d). Rather than focusing my analysis on details of this particular dialectic, I prefer in this commentary to explore the larger practical moral context within which these debates take place.

Canonical Western philosophy has been (and to a lesser degree, remains) rife with arguments denying reason, thought, and sentience to animals. ${ }^{1}$ Although Descartes's is the most notorious and perhaps extreme view in this regard - a view known as the bête-machine wherein animals are nothing more than reflexive automata - many philosophers from Aristotle to contemporary philosophers like Donald Davidson (1982) and Peter Carruthers (1989) deny (to varying degrees) mentation or even sentience to animals.

In response to immoderate views like Descartes's, Hume (2007/1739) boldly opens Book I, Section 16 of $A$ Treatise of Human Nature, "Of the reason of animals," by attacking such views as "stupid and ignorant":

Next to the ridicule of denying an evident truth, is that of taking much pains to defend it; and no truth appears to me more evident, than that beasts are endow'd with thought and reason as well as men. The arguments are in this case so obvious, that they never escape the most stupid and ignorant. (p. 118)

\footnotetext{
${ }^{1}$ Sneddon et al. note that "[s]ome authors even feel the need to refer to 'humans and animals,' as if humans were not themselves animals." Though I sometimes use the term "alloanimals" to refer to nonhuman animals, in this brief piece, I use the term "animal" to describe nonhuman animals while fully recognizing that humans are, in fact, animals.
} 
What reasons have philosophers and scientists offered to deny such an "evident" truth? Sneddon et al. suggest that sentience is often denied because "sentience is at the heart of the decision about whether to provide animals with legislative protection" (p. 3). This sentiment suggests that unwelcomed moral, social, and practical implications may motivate claims for sentience denial rather than objective empirical data in concert with the pursuit of truth. It is this aspect of sentience denial that I wish to explore in this brief commentary.

As noted, it is not uncommon to find arguments denying cognition or sentience - or arguments against employing the precautionary principle (Birch 2017) - to rely on more than merely data (in the case of science) or conceptual arguments (in the case of philosophy). These arguments often argue backwards from unacceptable practical consequences of taking seriously the sentience of some animals, to the conclusion that we can't take the proposition seriously. The general form of these arguments looks something like this:

1. If (certain species of) animals are sentient, then that would have practical consequence $X$.

2. $\mathrm{X}$ is unacceptable.

3. Therefore, (certain species of) animals are not sentient.

In Discourse on the Method (1988/1637), Descartes offers a number of arguments against animal sentience, one of which is this: since the possession of sentience requires an immortal soul that survives death, it is "unimaginable" that human souls should share the eternal afterlife with things such as flies and ants, oysters and sponges.

More recently, philosopher Peter Carruthers (1989) argues that since animals lack the ability to entertain second-order beliefs, the "experiences" of animals must be "nonconscious" and thus they feel no pain. Consequently, they are not the proper subjects of moral concern. In fact, Carruthers argues that we have a "moral imperative" to suppress our sympathies when we see an animal in severe "pain" since - given that they are merely reflexive automata - they are actually not in pain. Carruthers (1992) goes so far as to describe animal welfare as "an irrelevance to be opposed" (p. 168).

In a recent target article in this journal, Key (2016) denies fish sentience, warning against applying the precautionary principle in questions of fish welfare for fear of "catastrophic effects" including "inappropriate approaches to fish welfare" and negative economic impacts for the fishing industry (p. 3).

What all these views (and others like them) share is a resistance to the moral implications of taking animal sentience seriously. "Unacceptable" moral, practical, or economic consequences should not drive answers to empirical questions regarding animal sentience, specifically in this case, fish sentience. This is bad faith, plain and simple. ${ }^{2}$

With regard to the precautionary principle as applied to fish welfare (as with any decision that uses the precautionary principle), the proportionality of the risk of harm must be weighed against the cost and feasibility of a proposed action. In the case of fish, the number slaughtered annually is at least twelve times the size of the current human population. This is clearly a moral atrocity. By any moral calculus, applying the precautionary principle regarding fish welfare is reasonable and prudential, if not obligatory.

\footnotetext{
${ }^{2}$ See Sanbonmatsu's (2011) masterful essay on the relationship between speciesism and bad faith.
} 
Last, though I whole-heartedly applaud the work of Sneddon et al. (2018) as heroic in its rigor and tenacity as a counterattack in defense not only of fish sentience, but of fish, I think the question of fish sentience is actually a moral canard. Let me explain. Currently approximately 68 billion vertebrate land animals (Faunalytics 2018) - whom we know, with as close to scientific certainty as possible, are sentient - live lives of abject misery, while they suffer and die in grisly, ghastly, ghoulish ways, all for human consumption. Despite scientific consensus on cow/pig/chicken sentience, and despite legislative welfare regulations, animals still endure horrific unnecessary suffering at the hands of humans. What this shows is that the question of animal sentience is less about the pursuit of truth, and more about a speciesist agenda - a moral conclusion in search of data, scientific findings, and legitimating arguments. Near-certainty regarding sentience will not end speciesism nor human supremacy. That enterprise does not require better science, research methodologies, or conceptual arguments. That enterprise requires moral transcendence.

\section{References}

Birch, J. (2017) Animal sentience and the precautionary principle. Animal Sentience 16(1).

Carruthers, P. (1989) Brute experience. The Journal of Philosophy, 86(5), 258-269.

Carruthers, P. (1992) The animals issue: Moral theory in practice. Cambridge: Cambridge University Press. Davidson, D. (1982) Rational animals. Dialectica, 36(4), 317-327.

Descartes, R. (1988/1637) Selected philosophical writings (J. Cottingham, Ed.). Cambridge: Cambridge University Press.

Diggles, B. K. Arlinghaus, R., Browman, H. I., Cooke, S. J., Cowx, I.G., Kasumyan, A. O., Key, B., Rose, J. D., Sawynok, W., Schwab, A., Skiftesvik, A. B., Stevens, E. D., Watson, C. A., \& Wynne, C. D. L. (2017) Responses of larval zebrafish to low pH immersion assay. Comment on Lopez-Luna et al. Journal of Experimental Biology, 220(17), 3191-3192.

Faunalytics. Animal advocacy by numbers. https://faunalytics.org/animal-advocacy-by-numbers/, retrieved May 10, 2018.

Hume, D. (2007/1739) A Treatise of human nature: A critical edition (D. F. Norton \& M. J. Norton, Eds.). Key, B. (2016) Why fish do not feel pain. Animal Sentience 3(1).

Lopez-Luna, J., Al-Jubouri, Q., Al-Nuaimy, W., \& Sneddon, L. U. (2017a) Reduction in activity by noxious chemical stimulation is ameliorated by immersion in analgesic drugs in zebrafish. Journal of Experimental Biology, 220, 1451-1458.

Lopez-Luna, J., Al-Jubouri, Q., Al-Nuaimy, W., \& Sneddon, L. U. (2017b) Impact of analgesic drugs on the behavioural responses of larval zebrafish to potentially noxious temperatures. Applied Animal Behaviour Science, 188, 97-105.

Lopez-Luna, J., Al-Jubouri, Q., Al-Nuaimy, W., \& Sneddon, L. U. (2017c) Impact of stress, fear and anxiety on the nociceptive responses of larval zebrafish. PLoS One, 12(8), e0181010.

Lopez-Luna, J., Canty, M. N., Al-Jubouri, Q., Al-Nuaimy, W., \& Sneddon, L. U. (2017d) Behavioural responses of fish larvae modulated by analgesic drugs after a stress exposure. Applied Animal Behaviour Science, 195, 115-120.

Sanbonmatsu, J. (2011) The animal of bad faith: Speciesism as an existential project. In Critical theory and animal liberation (J. Sorenson, Ed.), 29-45. New York: Rowman \& Littlefield Publishers.

Sneddon, L. U., Lopez-Luna, J., Wolfenden, D. C. C., Leach, M. C., Valentim, A. M., Steenbergen, P. J., Bardine, N., Currie, A. D., Broom, D. M., \& Brown, C. (2018) Fish sentience denial: Muddying the waters. Animal Sentience 21(1). 


\section{UQÀM/ISC Cognitive Science Summer School June 26 - July 6 2018, Montreal, Canada}

\section{The Other Minds Problem: Animal Sentience and Cognition}

Overview. Since Descartes, philosophers know there is no way to know for sure what — or whether — others feel (not even if they tell you). Science, however, is not about certainty but about probability and evidence. The 7.5 billion individual members of the human species can tell us what they are feeling. But there are 9 million other species on the planet (20 quintillion individuals), from elephants to jellyfish to mammals, with which humans share biological and cognitive ancestry, but not one other species can speak: Which of them can feel — and what do they feel? Their human spokespersons — the comparative psychologists, ethologists, evolutionists, and cognitive neurobiologists who are the world's leading experts in "mind-reading" other species -- will provide a sweeping panorama of what it feels like to be an elephant, ape, whale, cow, pig, dog, chicken, mouse, fish, lizard, lobster, snail: This growing body of facts about nonhuman sentience has profound implications not only for our understanding of human cognition, but for our treatment of other sentient species.

Gregory Berns: Decoding the Dog's Mind with Awake Neuroimaging

Gordon Burghardt: Probing the Umwelt of Reptiles Jon Sakata: Audience Effects on Communication Signals PANEL: Reptiles, Birds and Mammals WORKSHOP: Kristin Andrews: The "Other" Problems: Mind, Behavior, and Agency

Sarah Brosnan: How Do Primates Feel About Their Social Partners?

Alexander Ophir: The Cognitive Ecology of Monogamy

Michael Hendricks: Integrating Action and Perception in a Small Nervous System

PANEL: Primates, Voles and Worms

WORKSHOP: Jonathan Birch: Animal Sentience and the Precautionary Principle

Malcolm MacIver: How Sentience Changed After Fish Invaded Land 385 Million Years Ago

Sarah Woolley: Neural Mechanisms of Preference in Female Songbird

Simon Reader: Animal Social Learning: Implications for Understanding Others

PANEL: Sea to Land to Air

WORKSHOP: Steven M. Wise: Nonhuman Personhood

Tomoko Ohyama: Action Selection in a Small Brain

(Drosophila Maggot)

Mike Ryan: "Crazy Love": Nonlinearity and Irrationality

in Mate Choice

Louis Lefebvre: Animal Innovation: From Ecology to

Neurotransmitters

PANEL: Maggots, Frogs and Birds: Flexibility Evolving

SPECIAL EVENT: Mario Cyr: Polar Bears

Colin Chapman: Why Do We Want to Think People Are

Different?

Vladimir Pradosudov: Chickadee Spatial Cognition

Jonathan Balcombe: The Sentient World of Fishes

PANEL: Similarities and Differences

WORKSHOP (part 1): Gary Comstock: $\underline{\text { A Cow's Concept }}$

of Her Future

WORKSHOP (part 2): Jean-Jacques Kona-Boun: Physical

and Mental Risks to Cattle and Horses in Rodeos
Joshua Plotnik: Thoughtful Trunks: Application of

Elephant Cognition for Elephant Conservation

Lori Marino: Who Are Dolphins?

PANEL: Mammals All, Great and Small

Larry Young: The Neurobiology of Social Bonding, Empathy and Social Loss in Monogamous Voles

WORKSHOP: Lori Marino: The Inconvenient Truth About

Thinking Chickens

Andrew Adamatzky: Slime Mould: Cognition Through

Computation

Frantisek Baluska \& Stefano Mancuso: What a Plant Knows and Perceives

Arthur Reber: A Novel Theory of the Origin of Mind:

Conversations With a Caterpillar and a Bacterium

PANEL: Microbes, Molds and Plants

WORKSHOP: Suzanne Held \& Michael Mendl: Pig

Cognition and Why It Matters

James Simmons: What Is It Like To Be A Bat?

Debbie Kelly: Spatial Cognition in Food-Storing

Steve Phelps: Social Cognition Across Species

PANEL

WORKSHOP: To be announced

Lars Chittka: The Mind of the Bee

Reuven Dukas: Insect Emotions: Mechanisms and

Evolutionary Biology

Adam Shriver: Do Human Lesion Studies Tell Us the Cortex is Required for Pain Experiences?

PANEL

WORKSHOP: Delcianna Winders: Nonhuman Animals in

Sport and Entertainment

Carel ten Cate: Avian Capacity for Categorization and

Abstraction

Jennifer Mather: Do Squid Have a Sense of Self?

Steve Chang: Neurobiology of Monkeys Thinking About

Other Monkeys

PANEL

WORKSHOP: The Legal Status of Sentient Nonhuman

Species 